NOTE

\title{
Intrusion of high-salinity water causes accumulation of transparent exopolymer particles (TEP) in the northern Adriatic Sea
}

\author{
Mirjana Najdek*, Maria Blažina, Dragica Fuks, Ingrid Ivančić, Tina Šilović \\ Center for Marine Research, Ruðer Bošković Institute, G. Paliaga 5, 52210 Rovinj, Croatia
}

\begin{abstract}
We present evidence that transparent exopolymer particles (TEP) accumulate in the northern Adriatic Sea as a result of the intrusion of oligotrophic high-salinity water (OHSW) from the south during summer. Samples were collected in June and July of 2007 in haloclines, and in the layers above and below them, at 2 stations in the region of the highest influx of OHSW. In June, we observed that concentrations of TEP in the upper part of the water column were 10 times higher at the eastern station as compared to the western station. This coincided with an intrusion of OHSW at the eastern station while the western station remained unaffected. In July, 2 stronger events involving OHSW encompassed both stations, leading to significant accumulations of TEP in the haloclines and in the layers above. Furthermore, during the period of maximal TEP accumulation, we noted pronounced increases in the abundance of diatoms and in bacterial numbers. These increases coincided with low cell-specific production of bacterial biomass, and a low abundance of actively respiring $(\mathrm{CTC}+)$ bacteria. In contrast, during the period of lower TEP concentration in the halocline, we observed an increase in the abundance of CTC+ bacteria, and in cell-specific $\beta$-glucosidase activity, probably indicating enhanced degradation of TEP in this layer.
\end{abstract}

KEY WORDS: Oligotrophic high-salinity waters - Transparent exopolymer particles - TEP · Bacterioplankton $\cdot$ Production $\cdot$ Activity $\cdot$ Halocline $\cdot$ Northern Adriatic Sea

Resale or republication not permitted without written consent of the publisher

\section{INTRODUCTION}

Transparent exopolymer particles (TEP) are either formed spontaneously from dissolved substances, constituents of colloidal dissolved organic matter (DOM), or formed directly by the release of particulate material by phytoplankton (Passow 2002). Both processes are stimulated by turbulence (Passow \& Alldredge 1994, Schuster \& Herndl 1995). In the northern Adriatic Sea, TEP concentrations are correlated with phytoplankton biomass, both decreasing from the western to the eastern part (Radić et al. 2005).

In the northern Adriatic Sea during summer, pronounced salinity gradients develop due to a combination of the eastward transport of low-salinity waters formed in the Po delta area and intrusions of oligotrophic high-salinity waters (OHSW) from the southern
Adriatic Sea (Giani et al. 2005, Russo et al. 2005). OHSW intrusion, associated with strong turbulence and complex internal hydrodynamics, creates conditions for the selective accumulation of organic particles and microphytoplankton (Najdek et al. 2005), thus representing hot-spots of microbial activity.

The aim of the present study was to verify the hypothesis that enhanced TEP accumulation during summer in the northern Adriatic Sea is related to intrusions of OHSW. Sampling was performed in areas where intrusions of OHSW were highest or were expected to be high. We therefore determined and compared concentrations of TEP above, below and within the halocline in June and July of 2007. To relate TEP to its producer and degrader compartments, we also determined microphytoplankton composition, chlorophyll a (chl a), as a proxy for biomass production, and changes in total bac- 
teria, actively respiring (CTC+) bacteria, bacterial production (measured by incorporation of ${ }^{3} \mathrm{H}$-leucine and ${ }^{3} \mathrm{H}$-thymidine) and $\beta$-glucosidase activity.

\section{MATERIALS AND METHODS}

Sampling and basic parameters. During monitoring cruises aboard the 'Vila Velebita' research vessel, from May 10 to July 26, 2007, salinity was determined by CTD profiler (Seabird) at 14 stations of the Rovinj-River Po transect in the northern Adriatic Sea (Fig. 1). Samples for TEP determination were taken with Niskin samplers at the surface, and at depths of 5, 10, 20 and $31 \mathrm{~m}$ at Stn SJ103. During additional cruises, conducted on June 11 (Stn SJ105) and July 16 (Stns SJ103 and SJ105, Fig. 1), seawater was collected by SCUBA divers with Niskin samplers placed horizontally at 4 depths. Except for surface samples, the choice of sampling points was made according to salinity data obtained by the CTD profiler to correspond to the halocline layer and the water layers above and below it. For determination of chl a concentration, seawater was filtered through GF/C filters, extracted in acetone (90\% v/v) and determined fluorometrically (Strickland \& Parsons 1972).

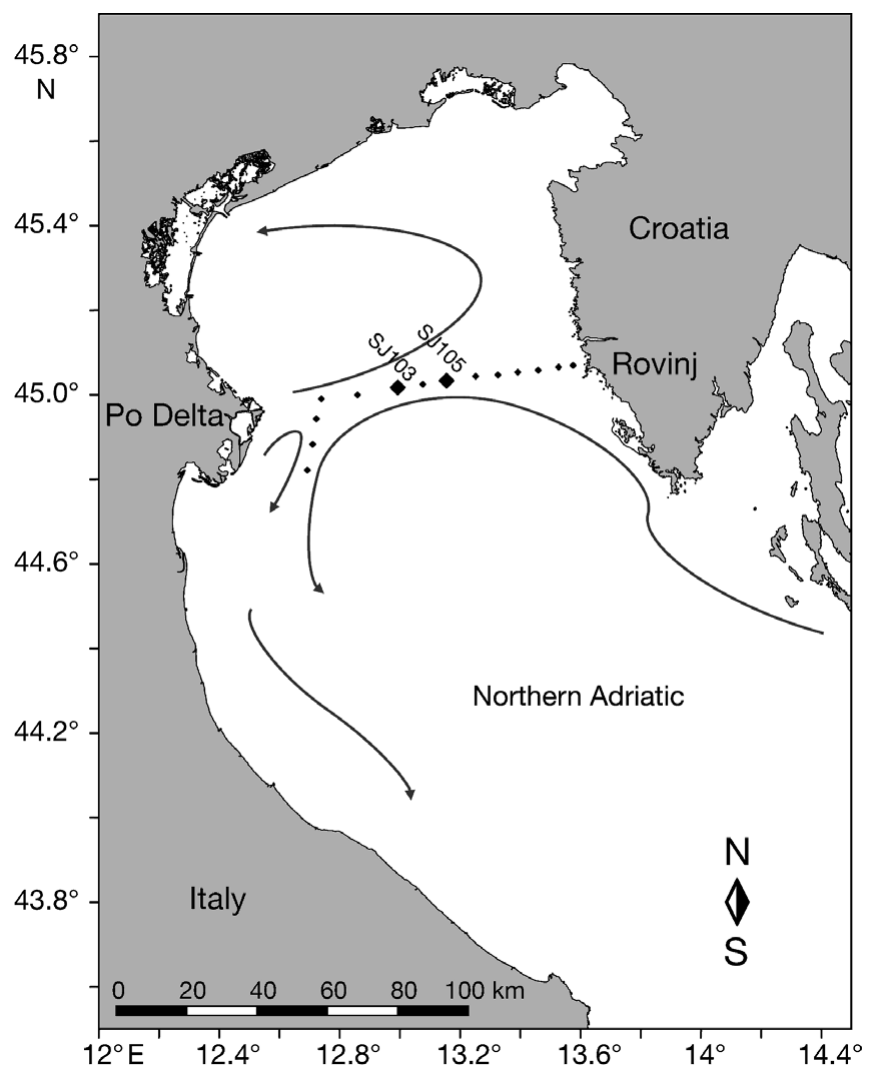

Fig. 1. Sampling stations (SJ103 and SJ105) in the northern Adriatic Sea. Directions of the main currents during summer are indicated by arrows
Microphytoplankton and TEP. For microphytoplankton counts, $200 \mathrm{ml}$ samples were preserved with Lugol's solution and stored at $4^{\circ} \mathrm{C}$. Microphytoplankton (i.e. cells or colonies $>20 \mu \mathrm{m}$ ) were identified and counted by an inverted microscope (Carl Zeiss) using the settling technique (Utermöhl 1958), e.g. the method of random fields $(50,100$ or 200 fields). For the concentration of TEP, samples $(20 \mathrm{ml})$ were preserved onboard with formaldehyde (final conc. $2 \%$ ), filtered through polycarbonate filters of pore size $0.4 \mu \mathrm{m}$, stained with a pre-filtered $(0.2 \mu \mathrm{m}$ pore size) $0.02 \%$ solution of Alcian blue (8GX, Sigma) in $0.06 \%$ acetic acid ( $\mathrm{pH} 2.5$ ) for $3 \mathrm{~s}$, transferred to beakers with $80 \%$ $\mathrm{H}_{2} \mathrm{SO}_{4}$ and determined spectrophotometrically at $787 \mathrm{~nm}$ (Passow \& Alldredge 1995).

Abundance of total heterotrophic bacteria (HB) and actively respiring $(\mathbf{C T C}+)$ bacteria. For determining the bacterial abundance, $2 \mathrm{ml}$ of samples were stained with DAPI (4',6-diamidino-2-phenylindole), at $1 \mu \mathrm{g}$ $\mathrm{ml}^{-1}$ final concentration, for $10 \mathrm{~min}$ and then passed through black polycarbonate filters of pore size $0.2 \mu \mathrm{m}$ (Nuclepore). Ultraviolet (UV) excitation with epifluorescence microscopy (Leitz Laborlux D) was used for counting (Porter \& Feig 1980). At least 500 single cells were counted for each sample at a final magnification of $1000 \times$. The abundance of respiring bacteria was determined with 5-cyano-2,3-ditolyltetrazolium chloride (CTC, final conc. $5 \mathrm{mM}$ ). A formaldehyde-killed control was prepared for each sample. The samples and control were incubated in darkness at $19^{\circ} \mathrm{C}$ for $4 \mathrm{~h}$. At the end of incubation, samples were fixed with formaldehyde and counterstained with DAPI on black polycarbonate filters of pore size $0.2 \mu \mathrm{m}$; they were then counted by epifluorescent microscopy (Rodriguez et al. 1992).

Bacterial heterotrophic production and $\boldsymbol{\beta}$-glucosidase activity. The rate of incorporation of ${ }^{3} \mathrm{H}$-leucine (Leu) and ${ }^{3} \mathrm{H}$-thymidine (TdR) into macromolecules was measured in order to estimate bacterial heterotrophic production (Kirchman et al. 1985, Smith \& Azam 1992, Fuhrman \& Azam 1982). Triplicates $(1.7 \mathrm{ml}$ aliquots) of samples were incubated with L- $\left[4,5-{ }^{3} \mathrm{H}\right]$ leucine (spec. activity $>100 \mathrm{Ci} \mathrm{mmol}^{-1}, 20 \mathrm{nM}$ final conc.) or methyl- ${ }^{3} \mathrm{H}$-thymidine (spec. activity $>70 \mathrm{Ci}$ $\mathrm{mmol}^{-1}, 20 \mathrm{nM}$ final conc.) in sterile $2.0 \mathrm{ml}$ microcentrifuge tubes for $1 \mathrm{~h}$ at $18 \pm 1^{\circ} \mathrm{C}$. Samples with $100 \%$ trichloroacetic acid (TCA), added before the addition of leucine, served as blanks. After incubation was terminated with $100 \%$ TCA, samples were centrifuged, the supernaant discarded, and the labelled material extracted consecutively with cold 5\% TCA and $80 \%$ ethanol and collected by centrifugation. Rates of cellspecific incorporation of leucine and thymidine were obtained by dividing the average rates per litre by bacterial abundance per litre. For determination of 
$\beta$-D-glucosidase activities we used 4-methylumbelliferyl- $\beta$-D-glucoside (final conc. $250 \mu \mathrm{M}$ ). The fluorescence of triplicates was measured fluorometrically immediately after the addition of substrate and after incubation (of up to $1 \mathrm{~h}$ ), under an excitation wavelength of $365 \mathrm{~nm}$, using the emission at $455 \mathrm{~nm}$ for methylumbelliferyl (Hoppe 1983).

\section{RESULTS}

During June 2007, oligotrophic high-salinity waters intruded into the northern Adriatic Sea through the entire lower part of the water column (>10 $\mathrm{m}$ depth) as shown for SJ103 (Fig. 2A). A more intensive 'breakthrough' was observed within intermediate layers at the eastern part of the northern Adriatic Sea, as shown for SJ105 (Fig. 2C). On July 12, 2 'breakthroughs' of OHSW were observed: in the lower part of the water column on the eastern part and intermediate layers in the central part. Reinforced between July 12 and 16, the OHSW combined with an eastward flow of lowsalinity waters in the upper layers of the water column, causing thinning, sharpening and compressing of layers within and above the halocline at both stations. In layers $5 \mathrm{~m}$ and $2 \mathrm{~m}$ thick in the haloclines at SJ103 and
SJ105, respectively, salinity increased by $\sim 0.9$. Belowhalocline waters $(>16.5 \mathrm{~m})$ showed very stable and uniform salinity values of 38.26.

At SJ103, in May and June, TEP was low $(\sim 50 \mu \mathrm{g}$ $\mathrm{l}^{-1}$ ) and similarly distributed through the water column. The concentrations increased on July 12 and achieved maximum values in the above-halocline and halocline layers on July 16 . On July 26, TEP decreased in all layers (Fig. 2B). In June, concentrations of TEP at SJ105 (Fig. 2D) were about 10 times higher compared to concentrations measured at SJ103 (Fig. 2B). The increase in TEP concentrations in all layers, mainly in the halocline $\left(1752 \mathrm{\mu g} \mathrm{l}^{-1}\right)$, was noted on July 16 (Fig. 2D).

The microphytoplankton community was dominated by diatoms (>96\%) in all samples. On June 11 at SJ105, Dactyliosolen mediterraneus was the dominant species in all layers. Chaetoceros spp. was present in surface, above-halocline and halocline layers. On July 16, at SJ105 and SJ103, various species of the genus Chaetoceros were dominant in surface, above-halocline and halocline layers. Species of the genus Nitzschia were present in all layers and predominant in below-halocline (OHSW) layers. Microaggregates were visible in the halocline layer on July 16 at SJ105.
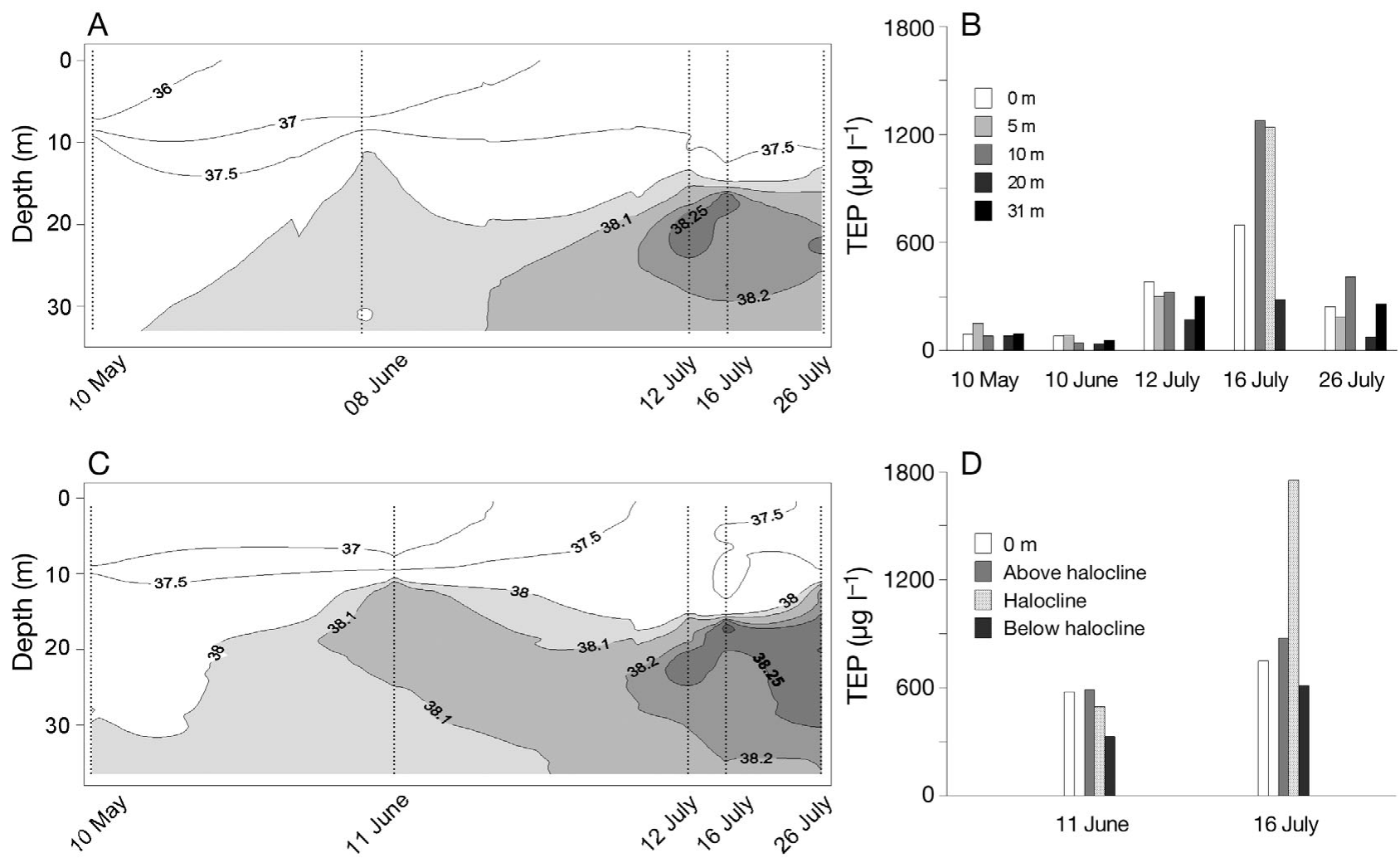

Fig. 2. Temporal distribution of salinity and concentrations of transparent exopolymer particles (TEP) at (A,B) SJ103 and (C,D) SJ105 
The abundance of microphytoplankton was the highest in haloclines in June and July at SJ105. The abundance in July was about 2 orders of magnitude higher than in June. At SJ103, the abundance of microphytoplankton was the highest in the surface layer, decreasing towards the OHSW layer (Fig. 3A). The abundance of Chaetoceros spp. in all sampling layers showed a very similar trend to total microphytoplankton. Concentrations of chl a were generally very low; slightly higher values were measured in halocline layers at all stations. In July, in these layers, the chl a concentrations were about double those measured in June (Fig. 3B).

The abundance of heterotrophic bacteria (HB) was lowest in OHSW layers at all sampling stations, while in haloclines it showed levels either very similar to or higher than those values in the OHSW layers in June and July, respectively. The highest abundance of HB was observed in the halocline layer at SJ103 (Fig. 3C).

The abundance of actively respiring $(\mathrm{CTC}+)$ bacteria showed a very similar trend between layers 'compared' to the HB only at SJ103. In June and July at SJ105, CTC+ abundances were similar slightly changing between layers. In comparison to SJ103, those values were evidently lower (Fig. 3D).
The cell-specific incorporation rates of leucine and thymidine showed analogous changes between the layers at all stations, being generally the lowest in June at SJ105. Both rates were lower in haloclines with respect to OHSW, as well as above-halocline layers in June and July at both stations (Fig. 3E,F).

Cell-specific $\beta$-D-glucosidase (GLU) activities were higher at SJ103, primarily in the halocline layer. In June and July at SJ105, GLU activities were the highest in OHSW and decreased towards the upper layers (Fig. 3G).

\section{DISCUSSION}

In June and July of 2007, oligotrophic high-salinity waters intruded into the intermediate layers of the northern Adriatic Sea. The accumulation of TEP in the haloclines, and in the layers above them, matched these events. In spite of the similar accumulation effect in those layers, the structure of the phytoplankton community and the corresponding bacterial activities differed, as did the TEP concentrations.

Inferred from the concentrations of chl $a$, phytoplankton biomass was low, as usually observed during
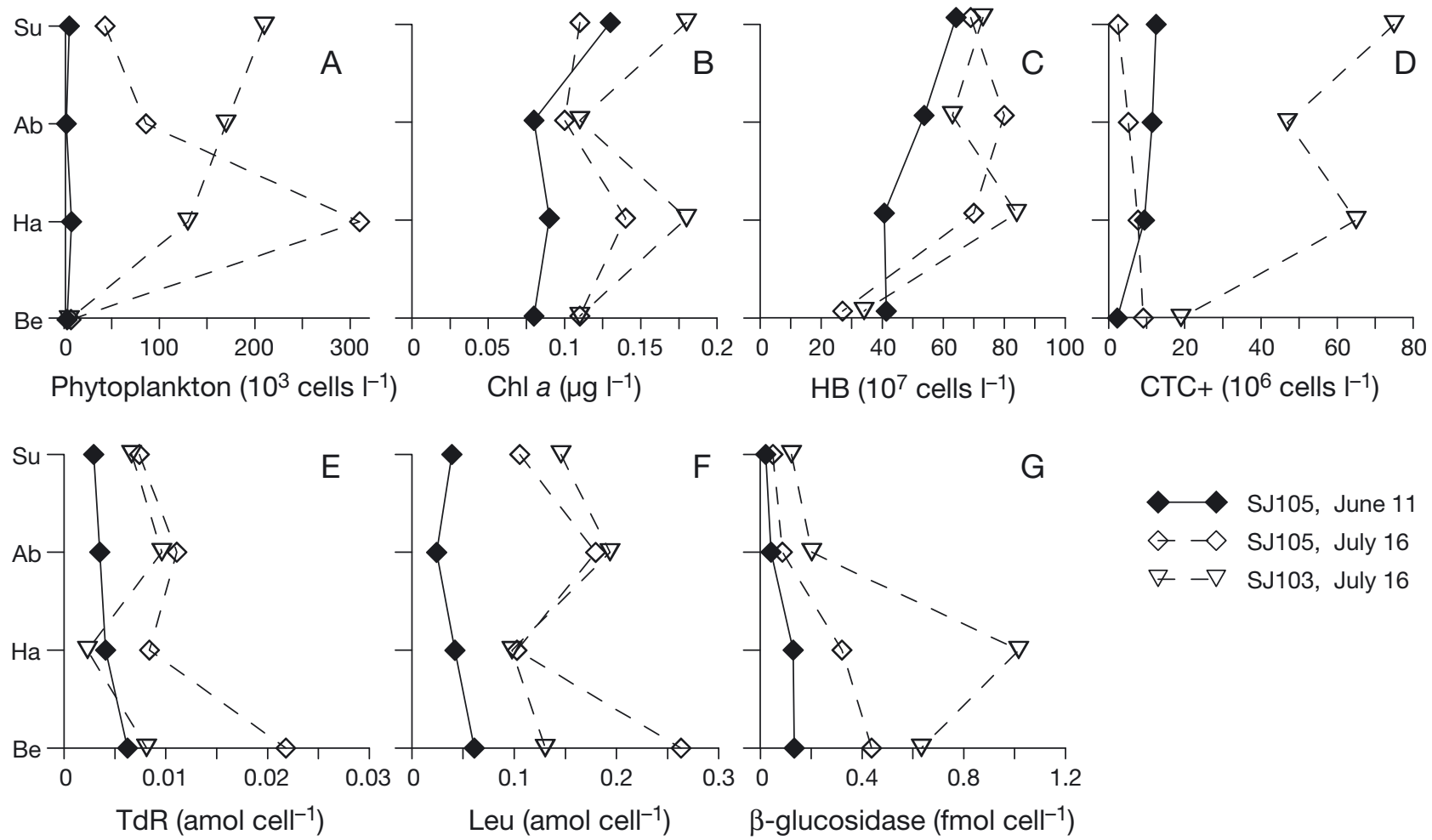

Fig. 3. (A) Abundance of phytoplankton, (B) chlorophyll a (chl a) concentrations, (C) heterotrophic bacteria (HB), (D) actively respiring bacteria $(\mathrm{CTC}+)$, (E) cell-specific incorporation of thymidine (TdR), (F) cell-specific incorporation of leucine (Leu), and $(\mathrm{G}) \beta$-glucosidase activity at surface $(\mathrm{Su})$, above-halocline $(\mathrm{Ab})$, halocline $(\mathrm{Ha})$ and below-halocline (Be) layers on June 11 and July 16 at SJ105 and SJ103 
summer in the eastern part of the northern Adriatic Sea (Radić et al. 2005). The presence of more abundant diatoms in halocline layers, particularly with respect to OHSW layers, resulted from their accumulation rather than production. In June, an evidently larger input of OHSW at SJ105, in contrast to SJ103, strengthened the halocline and compressed it into a thinner layer, causing accumulation of cells and TEP. These effects were even more pronounced in July at SJ105. The increase in salinity observed in a strong halocline indirectly implicates an increase in cations. Due to a 'cation bridging effect', the structural integrity of the negatively charged TEP was additionally stabilized (Chin et al. 1998, Simon et al. 2002). Wetz et al. (2009) referred to the influence of $\mathrm{pH}$ and temperature changes on TEP formation. However, it was shown that positive and negative correlation of $\mathrm{pH}$ and temperature, respectively, with TEP derived from co-variation of both parameters with salinity. Turbulence also contributes to enhance TEP formation and/or production (Schuster \& Herndl 1995). Though not measured directly, turbulence that might have contributed to high levels of TEP is expected to be greater under conditions of mixing and compression of the layers. In addition to spontaneously formed TEP, due to accumulation, the other possible mechanisms of TEP formation were production and release of cell surface-derived TEP (Wetz et al. 2009) that might have contributed to high TEP concentrations in July. Substantial TEP production probably derived from highly accumulated, mostly solitary, cells of congeneric Chaetoceros species. This genus is known to generate copious amounts of TEP and to form TEP-rich aggregates (Crocker \& Passow 1995).

The loss of bacterial metabolic activity, and the decline in cell-specific Leu and TdR uptake rates with respect to the OHSW layer, were observed at the highest concentration of TEP. A copious supply of organic matter, combined with low respiring and cell-specific GLU activities, prolonged a time lag between TEP formation and consumption. Such 'high production-low degradation' might have lead to the formation of numerous micro-aggregates observed in this halocline. In the halocline at SJ103, a minor decline in cellspecific activities, particularly in favour of biomass production, and a considerable increase in the abundance of actively respiring bacteria, mirrored by a comparable increase in the abundance of total bacteria, indicated advanced bacterial metabolic activity. Significantly higher cell-specific GLU activity with respect to all other layers pointed to a shift in the consumption of organic matter. GLU is induced due to the relative increase of high-molecular-weight compounds in DOM (Alonso-Saez et al. 2008). Therefore, the overall improvement in bacterial metabolic activity suggested partial degradation of TEP, reasonably explaining its lower concentration.

In conclusion, different patterns of enhanced TEP formation were observed during summer in the northern Adriatic Sea. These were realized under the favourable influence of high-salinity water intrusions. The physical-biotic coupling effect observed in July in the eastern part of the sampling region is highly relevant to the explanation of the appearance of a massive amount of mucilage that occurs periodically during summer in the northern Adriatic Sea (Najdek et al. 2005, Russo et al. 2005). Here, we have provided the first information on the effect of specific hydrographic conditions on the patterns of TEP distribution, though more intensive studies are necessary to verify the conclusions herein.

Acknowledgements. The authors thank SCUBA diver B. Jagić for sampling, P. Krelja, M. Buterer and S. Dujmović for technical assistance and A. Bakota for phytoplankton counting and taxa determination. The work is supported by the Ministry of Science, Education and Sports of the Republic of Croatia (Projects: 0982705-2729 and Jadran).

\section{LITERATURE CITED}

Alonso-Saez L, Vazquez-Dominquez E, Cardelus C, Pinhassi $\mathrm{J}$ and others (2008) Factors controlling the year-round variability in carbon flux through bacteria in a coastal marine system. Ecosystems 11:397-409

> Chin WC, Orellana MV, Verdugo P (1998) Spontaneous assembly of marine dissolved organic matter in polymer gels. Nature 391:568-572

> Crocker KM, Passow U (1995) Differential aggregation of diatoms. Mar Ecol Prog Ser 117:249-257

> Fuhrman JA, Azam F (1982) Thymidine incorporation as a measure of heterotrophic bacterioplankton production in marine surface waters: evaluation and field results. Mar Biol 66:109-120

> Giani M, Rinaldi A, Degobbis D (2005) Mucilage in the Adriatic and Tyrrhenian Sea: an introduction. Sci Total Environ 353:3-9

> Hoppe HG (1983) Significance of exoenzymatic activities in the ecology of brackish water: measurements by means of methyllumbelliferyl substrates. Mar Ecol Prog Ser 11: 299-308

> Kirchman D, K'nees E, Hodson R (1985) Leucine incorporation and its potential as a measure of protein synthesis by bacteria in natural aquatic systems. Appl Environ Microbiol 49:599-607

Najdek M, Blažina M, Djakovac T, Kraus R (2005) The role of the diatom Cylindrotheca closterium in a mucilage event in the northern Adriatic Sea: coupling with high salinity water intrusions. J Plankton Res 27:851-862

Passow U (2002) Transparent exopolymer particles (TEP) in aquatic environments. Prog Oceanogr 55:287-333

Passow U, Alldredge AL (1994) Distribution, size, and bacterial colonization of transparent exopolymer particles (TEP) in the ocean. Mar Ecol Prog Ser 113:185-198

Passow U, Alldredge AL (1995) A dye binding assay for the spectrophotometric measurement of transparent exopolymer particles (TEP). Limnol Oceanogr 40:1326-1335 
Porter KG, Feig YS (1980) The use of DAPI for identification and counting aquatic microflora. Limnol Oceanogr 25: 943-984

Radić T, Kraus R, Fuks D, Radić J, Pečar O (2005) Transparent exopolymeric particles' distribution in the northern Adriatic and their relation to microphytoplankton biomass and composition. Sci Total Environ 353:151-161

Rodriguez GG, Phipps D, Ishiguro K, Ridgway HF (1992) Use of fluorescent redox probe for direct visualization of actively respiring bacteria. Appl Environ Microbiol 58: 1801-1808

Russo A, Maccaferri S, Djakovac T, Precali R and others (2005) Meteorological and oceanographic conditions in the northern Adriatic Sea during the period June 1999-July 2002: influence on the mucilage phenomenon. Sci Total Environ 353:24-38

Schuster S, Herndl GJ (1995) Formation and significance of

Editorial responsibility: Hans-Georg Hoppe, Kiel, Germany transparent exopolymeric particles in the Northern Adriatic Sea. Mar Ecol Prog Ser 124:227-236

Simon M, Grossart HP, Schweitzer B, Ploug H (2002) Microbial ecology of organic aggregates in aquatic ecosystems. Aquat Microb Ecol 28:175-211

Smith DC, Azam F (1992) A simple, economical method for measuring bacteria protein synthesis rates in seawater using ${ }^{3} \mathrm{H}$-leucine. Mar Microb Food Webs 6:107-114

Strickland JDH, Parsons TR (1972) A practical handbook of seawater analysis. Bull Fish Res Board Can 167:1-310

Utermöhl H (1958) Zur Vervollkommnung der quantitativen Phytoplankton-Methodik. Mitt Int Verein Theor Ang Limn 9:1-38

Wetz MS, Robbins MC, Pearl HW (2009) Transparent exopolymer particles (TEP) in a river-dominated estuary: spatial-temporal distributions and an assessment of controls upon TEP formation. Estuar Coast 32:447-455

Submitted: March 9, 2010; Accepted: November 16, 2010 Proofs received from author(s): January 31, 2011 